\title{
Parent and Child Communication Patterns in Early Childhood Emotional Social Development
}

\author{
Nuzulul Hidayah ${ }^{1, *}$ G.D. Lestari ${ }^{1}$ I.K.A.J. Artha ${ }^{1}$ \\ ${ }^{1}$ Universitas Negeri Surabaya \\ "Corresponding author. Email: nuzulul.20004@mhs.unesa.ac.id
}

\begin{abstract}
This study aims to analyze the communication patterns of parents and children in social-emotional formation, especially for early childhood. The method used in this research is a literature study, which begins with problem identification to analysis and discussion. As for the results of this study which from various communication patterns, good and effective communication patterns are communication patterns that contain good values, children can empathize and sympathize, children have honesty, children have high consistency, and open interactive communication between children and parents.
\end{abstract}

Keywords: Parent-Child communication, Social-Emotional formation, Early childhood.

\section{INTRODUCTION}

The role of early childhood education in determining child development and preparing children to be ready to enter the world of higher education is quite important. Early childhood education is primary education held with an emphasis on the growth and development of children [1]. Early childhood education aims to lay the foundation for developing behaviour, knowledge, skills, and creativity so that children can develop their potential.

According to Mansur [2], early childhood is between the ages of $0-6$ years, where children are in a unique process of change and development. It is said to be unique. Children have growth and development (fine motor coordination and gross motor), intelligence (thinking power, creativity, and religion), and particular language and communication according to children's level of growth and development. The Golden Age period is vulnerable in children aged 0-6 years. This period plays a vital role in child development. Early childhood brain development reaches $80 \%$, which shows that all the potential of children begins to form at that age [3].

It was concluded that early childhood from 0-6 years is also known as the Golden Age. This period begins to form the development and potential of early childhood. Thus, children need a stimulus from an early age to optimize the development of their potential. Stimulus is obtained from parents, family, school, and community. The potential development of each child has its level.

Early childhood education carried out by parents should be by the intelligence, desires, or talents, and interests of children. However, many parents do not understand and realize the responsibility and importance of children's education. Intelligent children in terms of I.Q., emotional, and spiritual need cooperation between parents, schools, and the community. The gap in society is parents' lack of understanding in educating or stimulating children to increase optimal growth and development. As a parent, we must understand how the interaction between parents and children, parent-teacher communication, and the provision of facilities for children's education [4].

Child development is an integral part of a scientific paradigm by assuming that the world view is positivist. Child development has a long tradition in early childhood education and is primarily based on psychology, particularly developmental psychology and the interdisciplinary field of children in biology [5]. One aspect of early childhood development, namely social and emotional

Socio-emotional is the behaviour and feelings of an individual who relates to other people. Social-emotional in early childhood is a behaviour change accompanied by a pervasive feeling about early childhood relating to other people. Emotion is a practical experience that accompanies general inner adjustment and mental and 
physiological states within the individual and shows an open behaviour [6]. The Center for Social-Emotional Foundations for Early Learning (CSEFEL) reveals that social-emotional is the development of children from birth to the age of 5 years to form close relationships between children and adults and peers. Children's social emotions include experiencing, organizing, and expressing according to the culture and environment in learning [7].

The family is the leading and first education for children because the child's stimulus is first obtained in the family and in the child's family spending time. People who know have the responsibility to pass on good values to their children. Values in children can be inherited through family education - the critical role of parents in determining the direction and personality of the child to be formed. In the pedagogic context, parents are not justified in letting parents guide and supervise the growth and development of children. Guidance is given in a clear direction and directs children to the straight path. Education in the family should provide a basis for children's education and socialization in social life [8].

Excellent and harmonious family relationships are the primary keys to good communication. In family education, communication between parents and children is no less critical, and communication becomes a bridging medium in a relationship between family members. Without communication, family life will be lonely, so talk, dialogue, and exchange ideas [9]. The quality of communication provided will affect the child's social and emotional. The communication needed is interactive communication, where the father, mother, and child are involved in pleasant communication and avoid dominant or dominant communication.

Parent-child communication should also be encouraging, caring, and appreciative. Parental communication will determine the quality of the child's personality and morals. The key to family moral education is open communication and close relationships. Communication between parents and children should be encouraging, respectful, and caring [10]. However, some parents use violence to discipline their children, forbidding under the pretext of protecting and calculating in giving affection to make children independent. A large number of children causes children to be haunted by fear, lack of confidence, and a sense of anxiety. Children need experience and learning to develop social behaviour so that the community well receives them. Experience can teach others lessons and can increase friendship and responsibility for their actions [11]. Optimizing the development and learning of children is the guidance of parents and teachers. Teachers and parents must understand the commitment and clear communication with children to achieve children's development adequately [12].
Communication is a process of delivering information to other people. Delivering information involves the activity and creativity of those who deliver and who will receive messages or information. It can be said that communication is the creation of an idea or idea that aims to be conveyed to informants [13]. Gode (1965), quoted by [14], reveals that the meaning of communication is "it is a process that makes common to or several what the monopoly of one or some."

Communication patterns are models that have components and are connected in the form of symbols, have meaning, and aim to convey messages or information to change individual behaviour. The messages or information conveyed can be easily understood. Communication patterns conveyed by both adults to children and children to their peers have different patterns or models of communication. The socially-oriented parental communication pattern will significantly affect the child's role as an influencer in making decisions. Concept-oriented communication patterns will positively affect the role of children as influencers [15].

Family communication patterns affect the mental development and mindset of children, either directly or indirectly. Families will function optimally if open communication patterns, mutual acceptance, support, security, comfort, and spiritual life are maintained [16]. Several experts express various points of view on family education. According to Mansur, family education is a process of giving positive value to children's growth and development as further education [17]. Meanwhile, Abdullah argues that family education is all the efforts made by the family in terms of habituation and improvisation to help the child's personal development [18]. So family education is education carried out by families to provide positive values as the foundation for further child education, family education in the form of habituation and improvisation to help children's personal development.

The process of parent education in the family has several educational activities, including physical or physical education of children, academic education of children, religious, moral education, social education, and emotional education of children. Parents interacting with children must display positive behaviour patterns because parents' behaviour patterns will affect the stimulus for the child himself. One of the processes of parental education for children is emotional education because emotions will determine the child's personality for the future [19].

Based on the results of an interview with the principal of RA Baitul Muttaqiem on March 9, 2021, most student guardians have different professions, including civil servants, teachers, housewives, traders. Thus the role of parents in the family is significant for children who will affect the lives of children to 
adulthood. Establishing good communication between parents and children by looking at the various conditions and backgrounds of parents is quite tricky, and forming an excellent social-emotional child requires a short time. However, it takes a long process and time. Thus, education in the family needs patience and sensitivity, mainly how parents communicate well, which can trigger children's social-emotional development.

\section{METHODS}

The method used in this research is a literature study method. The data collected by this method are sourced from journals, books, and other sources. The database in this study is the newer the source, the more references, and the latest citations and effective databases are under the guidelines in the study. Literature study is research conducted by collecting sources through books and papers related to research objectives and problems [20]. The literature study approach can provide knowledge of the communication model of parents and children in the social-emotional formation of early childhood. This study examines more than 30 journals related to parentchild communication and children's social-emotional development. The data obtained were compiled, analyzed, and concluded to obtain conclusions regarding the study of literature.

\section{LANGUAGE AND DISCUSSION}

Parents must be responsible for children's social, emotional, and mental formation; parents must also give children attention, protection, and security. Thus parents must maintain good relations with children, in a family good communication is a must that cannot be avoided.

Good communication between parents and children will create harmonious relationships in the family. Building good communication can be done with various patterns. The communication pattern that is applied will affect the child's social, emotional, and psychological development.

Excellent and effective communication patterns are fundamental in family and social life. The following are some of the communication patterns used in providing information:

\section{1) Permissive communication pattern}

A permissive communication pattern is a communication pattern in which parents act indifferent or do not care what happens to their children, giving them freedom [21]. The permissive communication pattern is the all-encompassing one in which parents are submissive, comply with all desires, and protect excessively. Children in this permissive communication pattern are characterized by following the child's wishes and unlimited freedom.

\section{2) Authoritative communication pattern}

Traditional communication patterns tend to impose their will. Parents act more as a supervisor (control) over everything about their children used by PAUD children, kindergarten children, and used for elementary school children with some instances [22]. The role of parents is flexible in this communication pattern which is also aimed at the child's unique behaviour personality. Parents provide freedom accompanied by guidance to children. Children will be given input and direction and all questions answered wisely and openly by parents.

\section{3) Laissez-faire communication pattern}

This lasses-fair communication pattern can be implemented for all age levels of children. This communication pattern is not based on rules and parents provide unrestricted freedom for children and with little parental intervention [22].

\section{4) The paternalistic communication pattern}

The paternalistic communication pattern is a fatherly communication pattern, which means that parents act as fathers to their children in educating, nurturing, teaching, guiding, and advising [22].

\section{5) Self-melting communication patterns}

This self-melting communication pattern is a type of leadership in which parents prioritize cooperation and combine themselves with their children [22].

\section{6) Pioneer style communication pattern}

In this pioneer-style communication pattern, parents are always pioneers where parents provide examples of kindness for children and families [22].

\section{7) Manipulation communication pattern}

In this manipulation communication pattern, parents always do tricks, twist reality, and give rules to children, with the aim that children do what their parents want [22].

8) Communication patterns so that they are slow as long as they are safe

In this communication pattern, parents are always careful about what they do. This parent has the principle that even if it is slow, as long as it is safe and even if it is slow, let it jump far ahead [22].

9) Role switching communication patterns

In this type, parents give authority or provide opportunities for children to develop tasks or roles with parents who continue to provide direction, supervision, and facilitation [22].

10) Selfless communication pattern 
This communication pattern is selfless because each child's work is given or assessed with material to move the child to do something the parents want [22].

\section{1) Selfless communication pattern}

In this communication pattern, parents raise children by teaching sincerity in words, behaviour, and deeds. It is said to be selfless because whatever they do, they expect rewards or gains, except for the pleasure of God [22].

\section{2) Consultant communication pattern}

In this communication pattern, parents act as good listeners or a place for children's complaints. In this communication, parents act as consultants and children as messengers. In this communication, both parties are involved in communication [22].

\section{3) The militaristic pattern of communication}

This pattern acts like commanding. The child must obey any orders from the parents without any objections. The child must be obedient to the orders and prohibitions of the parents. In conditions such as threats, dangerous conditions, this type is very appropriate to use for the safety of children [22].

Some of the communication patterns above can be used as a basis by parents in establishing good communication with early childhood. These communication patterns have positive and negative impacts, so parents must adjust to the child's condition. Good communication between parents and children affects the development of children, one of which is social-emotional development. Socio-emotional in early childhood is the behaviour and feelings of a child related to other people. Emotions in early childhood are shown by various responses related to interactions in the environment [23]. Socio-emotional development in children after an early age, especially for ages 2-4 years, has its level. There are three levels of emotional, social development in early childhood: self-awareness, responsibility, and others, and levels of social behaviour. According to [24], the socio-emotional development of early childhood is influenced by several factors, including heredity and environmental factors. The hereditary factor is the first factor that affects the growth and development of children or is also called heredity. Meanwhile, environmental factors are situations and conditions from outside the individual that directly or indirectly affect the growth and development of children.

Social-emotional abilities in children exist from birth. Every individual has basic social and emotional, but as children get older and interactions with other people will affect the social and emotional development of children. Thus it can be said that the environment influences social-emotional development. Children's social-emotional development is needed with interactions between adults and children; adults have responsibilities in children's social, emotional, cognitive, academic, and behavioural skills [25]. Children will absorb based on behaviour, assessment, and treatment from parents, family, peers, and the community in the learning process. Children's learning initially takes place in the family, so that the family becomes a determining factor in children's socialemotional development. So, in this case, the communication pattern used by the family, especially parents, will influence and determine the social and emotional development of children.

Open parent-child communication is one aspect of a good parent-child relationship and plays an essential role in maintaining the family system and child development. Communication also maintains close family relationships, which will provide an effective quality contribution in maintaining the relationship between parents and children. The use of communication in children will introduce and improve the child's self-identity, children can share experiences and understand the experiences of others, and with the use of communication, they can compare themselves so that they can purify the emotional social in children [26].

The use of communication patterns describes the interaction between family members, especially between children and parents. The communication pattern used in the family is influenced by several factors, including economic factors, social factors, living environment factors, educational factors, and beliefs held and will not be separated from cultural factors, patterns of action, norms, values, and ideas or ideas that are used as symbols to communicate in a family.

\section{CONCLUSION}

Social and emotional formation in early childhood can be done by maintaining good relationships and communication between parents and children. Communicative patterns of parents and children consist of permissive communication patterns, authoritative communication patterns, laissez-faire communication patterns, paternalistic communication patterns, selfmelting communication patterns, pioneering style communication patterns, manipulation communication patterns, communication patterns so that they are slow to survive, patterns selfless communication, selfless communication pattern, militaristic communication pattern. Each of these communication patterns has its advantages and disadvantages.

Parents should pay attention to the communication patterns provided. The communication pattern that is applied will affect the psychological and personality 
development of a child. Based on the discussion and explanation above, parents can use effective communication patterns in forming an excellent socialemotional child.

In order to achieve good communication in improving the socio-emotional development of early childhood, it is necessary to socialize from an early age to families. The socialization process will be good if supported by religious, cultural factors, and under the times so that children will know good and bad values, sympathy, empathy, selfishness, honesty, cooperation, and consistency. These things will grow in an atmosphere of democratic, interactive, and open communication between parents and children.

\section{ACKNOWLEDGMENTS}

The author would like to thank the supervising lecturers of Non-Formal Education at the Postgraduate level who have provided input and suggestions to the author to complete this article. The author would also like to thank the reviewer team and the Journal Editors who have provided the opportunity to publish the author's results. Hopefully, this article can be helpful for writers and readers.

\section{REFERENCES}

[1] Mursid, Belajar dan Pembelajaran, Remaja Rsdakaya, 2015.

[2] A. Wardhani, Studi deskriptif nilai keagamaan anak usia dini pada kelaurga bermatapendaharian di luar kota di Desa Pengarasan Kabupaten Tegal, 2004.

[3] P.H. Pebriana, "Analisi penggunaan gadget terhadap kemampuan interaksi sosial pada anak usia dini," Jurnal Obsesi : Jurnal Pendidikan Anak Usia Dini, pp. 1-11, 2017.

[4] N. Cholimah, "Upaya peningkatan partisipasi orang tua dan kualitas pendidik pada pendidikan anak usia dini," CAKRAWALA Jurnal Pendidikan Anak Usia Dini, 2017.

[5] L.D. Soto, Toward liberatory early childhood theory, research and praxis: Decolonizing a field. Contemporary Issues In Early Childhood, 2002.

[6] Baharudin, Pendidikan dan Psikologi Perkembangan, Ar-Russ Media, 2010.

[7] D.M. Ashdown and EM. Bernard, "Can explicit instruction in social and emotional learning skills benefit young children's social-emotional development, well-being, and academic achievement of young children?," Early Childhood Educ J, pp. 397-405, 2012.
[8] M. Hasan, Pendidikan Anak Usia Dini, Diva Press, 2009.

[9] S.B. Djamarah, Pola Komunikasi Orangtua \& Anak Keluarga, Rineka Cipta, 2004.

[10] N.A. Iyoq, "Efektivitas komunikasi orang tua pada anak dalam membentuk perilaku positif," Jurnal Komunikasi, 2017.

[11] P. Soto-Icaza, F. Aboitiz and P. Billeke "Development of social skills in children: neural and behavioral evidence for the elaboration of cognitive models," Front. Neurosci, vol.9, no.333, 2015, doi: 10.3389/fnins.2015.00333

[12] L.K. Pertiwi, A. Febriyanti, Y. Rachmawati, "Keterlibatan orang tua terhadap pembelajaran daring anak usia dini pada masa pandemi covid 19," CAKRAWALA Jurnal Pendidikan Anak Usia Dini, 2021.

[13] P.S.W. Irawan, Teori belajar motivasi dan keterampilan mengajar, Pusat Antar Universitas Untuk Peningkatan Dan Pengembangan Aktifitas Instruksional, Directorat Jenderal Pendidikan Tinggi Departemen Pendidikan Dan Kebudayaan, 2000 .

[14] Wiryanto, Pengantar Ilmu Komunikasi, Grasindo, 2004.

[15] S. Budiman and W. Tomi, "Communication pattern of Indonesia parents-children and its role in buying decision," Global Business \& Finance Review, pp. 102-108, 2016

[16] I. Nurlita, R. Setyahajoe, "Interpersonal communication pattern of broken home's teens with their parents in Surabaya to minimize juvenile delinquency," Academic Research International, 2014.

[17] Mansur, Pendidikan Anak Usia Dini dalam Islam. Pustaka Pelajar, 2005.

[18] M.I. Abdullah, Pendidikan Keluarga Bagi Anak. Lektur, 2003.

[19] F. Yasin, Dimensi-dimensi Pendidikan Islam, UIN Malang Press, 2008

[20] D. Wasriah, Metode Penulisan Karya Ilmiah, Laboratorium Pendidikan Kewarganegaraan UPI, 2009.

[21] Y. Samsu, Psikologi Perkembangan Anak dan Remaja, Remaja Rsdakaya, 2000.

[22] S.B. Djamarah, Pola Asuh Orang Tua dan Komunikai dalam Keluarga, PT Rineka Cipta, 2014. 
[23] M. Fadhilah, Pendidikan Karakter Anak Usia Dini, Ar-Russ Media, 2014.

[24] Nurjannah, "Mengembangkan kecerdasan sosial emosional anak usia dini melalui keteladanan," Hisbah:Sosial Emosional Konseling Dan Dakwah Islam, 2017.

[25] A. Mona, A. Manal, A. Amani, "Pengaruh kompetensi sosial-emosional terhadap prestasi akademik anak dan perkembangan perilaku," International Education Studies, 2019.

[26] L.S. Tubbs and S. Moss, Human Communication:
Prinsip-Prinsip Dasar, Buku Pertama. (Terjemahan Deddy Mulyana dan Gembirasari, Remaja Rosdakarya, 1996. 